\title{
Comparison of hybridizing options for solar heat, biomass and heat storage for electricity generation in Spain
}

CM Iftekhar Hussain

Technological University Dublin, CMIftekhar.Hussain@TUDublin.ie

Brian Norton

Technological University Dublin, brian.norton@tudublin.ie

Aidan Duffy

Technological University Dublin, aidan.duffy@tudublin.ie

Follow this and additional works at: https://arrow.tudublin.ie/dubenart

Part of the Biomedical Engineering and Bioengineering Commons, Operations Research, Systems

Engineering and Industrial Engineering Commons, and the Other Engineering Commons

\section{Recommended Citation}

C.M. Iftekhar Hussain, Brian Norton, Aidan Duffy, Comparison of hybridizing options for solar heat, biomass and heat storage for electricity generation in Spain, Energy Conversion and Management, Volume 222, 2020, 113231, ISSN 0196-8904, https://doi.org/10.1016/j.enconman.2020.113231. (https://www.sciencedirect.com/science/article/pii/S0196890420307755)

This Article is brought to you for free and open access by the Dublin Energy Lab at ARROW@TU Dublin. It has been accepted for inclusion in Articles by an authorized administrator of ARROW@TU Dublin. For more information, please contact arrow.admin@tudublin.ie, aisling.coyne@tudublin.ie,gerard.connolly@tudublin.ie. Funder: TU Dublin; Science Foundation Ireland

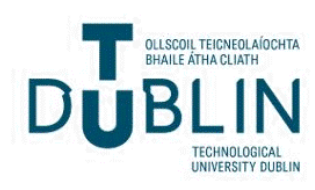




\title{
Comparison of hybridizing options for solar heat, biomass and heat storage for electricity generation in Spain
}

\author{
C.M. Iftekhar Hussain ${ }^{\mathrm{a}, *}$, Brian Norton ${ }^{\mathrm{a}, \mathrm{b}}$, Aidan Duffy ${ }^{\mathrm{a}, \mathrm{b}}$ \\ ${ }^{a}$ Dublin Energy Lab, Technological University Dublin, Grangegorman, Dublin 7, Ireland \\ ${ }^{\mathrm{b}}$ MaREI, the SFI Research Centre for Energy, Climate and Marine
}

\section{A R T I C L E I N F O}

\section{Keywords:}

Concentrated solar power

CSP-biomass

Thermal energy storage

\begin{abstract}
A B S T R A C T
Diurnal and seasonal variations of direct solar energy circumscribe locations suitable for sole use of concentrated solar power for electricity generation, whereas to generate electricity at night and during winter months, biomass systems can be used that incur fuel expenditures and may encounter fuel supply discontinuities. Combining solar heat, biomass conversion and heat storage in a hybrid electricity generation plant may overcome the limitations of sole use of any one of these energy sources in specific geographic and/or economic conditions. In this work standalone biomass, hybrid concentrated solar power-biomass and hybrid concentrated solar powerbiomass-thermal energy storage power generation systems are simulated. With an $80 \%$ plant capacity factor for each power plant configuration, levelized cost of electricity is calculated using the simulated fuel consumption. In a comparative analysis, the hybrid concentrated solar power-biomass power plant is found to be an economically viable option having $25 \%$ lower levelized cost of electricity compared to a hybrid concentrated solar power-biomass- thermal energy storage power plant in a particular scenario considered.
\end{abstract}

\section{Introduction}

Concentrating Solar Power (CSP) electricity generation systems without storage or a dispatchable auxiliary energy source, may not satisfy grid power demands due to variations in solar energy intensity (i.e., day/night cycles and lower irradiation in winter) [1]. Consequentially, this adversely affects the economic viability [2]; thus limiting their uptake in many regions [3]. To address this, such power plants either integrate storage of solar-generated electricity/heat, or include a non-solar electricity generation system [4]. In regions with moderate solar irradiance where sustainable and reliable biomass resources are also available, it may be a viable option to use a hybrid solar-biomass plant that harnesses two or more energy sources to cogenerate electrical power in a single plant [5]. As such hybrid systems require less bulk biomass storage, they could have a lower initial cost than stand-alone biomass systems [6]. Hybridizing a biomass plant with solar also reduces reliance on uncertain biomass feedstock supply chains [7]. An efficient non-intermittent hybrid CSP-biomass power generation system may thus be able to operate over a greater range to include regions that have medium Direct Normal Irradiance (DNI) [8]. On sunny days, steam can be generated solely from the solar energy system [7]. During cloudy days, the biomass system supplements solar energy output to maintain power generation [9]. At night, energy may be generated solely from biomass [10].

A solar fraction of an electric power plant may be improved by integrating a high temperature thermal energy storage (TES) system that may further reduce costs associated to biomass resource usages [11]. The required operation time of the biomass system can be reduced by charging TES from excess solar energy produced in a day to discharge the stored thermal energy at night [12]. TES systems are, however, very costly and can greatly increase the overall capital cost of the hybrid plant. A significant challenge, therefore, is to reduce the cost of integrating the TES system through design and manufacturing efficiencies [13]. As the cost for the TES can be high, detailed cost analyses are necessary to determine an economic viability of a hybrid CSP-biomassTES power plant [14].

The work presents techno-economic parameters of a hybrid CSPbiomass power plant that influence their commercial uptake. This also evaluates the potential cost of electricity for three power plant configurations that enables a parametric analysis to identify best economically feasible hybrid CSP-biomass power plant. To calculate the cost of electricity for power plant configurations, the key techno-economic parameters have been obtained from TRNSYS 17 simulation results. Levelized cost of electricity (LCOE) is used as a basis for economic comparison. All plant configurations are evaluated by varying capacity factor and capital cost to identify key parameters that influence cost

\footnotetext{
* Corresponding author.

E-mail address: d14124785@mytudublin.ie (C.M.I. Hussain).
} 


\author{
Nomenclature \\ CAPEX Capital expenditure $(€ / \mathrm{kW})$ \\ CSP Concentrated Solar Power \\ DNI Direct Normal Irradiance $\left(\mathrm{kWh} / \mathrm{m}^{2}\right)$ \\ DSG Direct Steam Generation \\ HTF Heat Transfer Fluid \\ $\mathrm{KNO}_{3} \quad$ Potassium nitrate \\ LCOE Levelized Cost of Electricity $(€ / \mathrm{kWh})$ \\ $\mathrm{NaNO}_{3}$ Sodium nitrate \\ ORC Organic Rankine Cycle \\ PLR Part Load Ratio
}

$\begin{array}{ll}\text { SAM } & \text { System Advisor Model } \\ \mathrm{TES} & \text { Thermal Energy Storage } \\ \mathrm{h}_{\text {in }} & \text { Enthalpy of input steam }(\mathrm{J} / \mathrm{Kg}) \\ \mathrm{h}_{\text {out,ideal }} & \text { Ideal enthalpy of exiting steam }(\mathrm{J} / \mathrm{Kg}) \\ \mathrm{h}_{\text {out,actual }} & \text { Actual enthalpy of exiting steam }(\mathrm{J} / \mathrm{Kg}) \\ i & \text { number of years } \\ \mathrm{m}_{\text {in }} & \text { Mass flow rate of input steam }(\mathrm{Kg} / \mathrm{hr}) \\ n & \text { expected lifetime (year) } \\ \mathrm{P}_{\text {in }} & \text { Input power }(\mathrm{W}) \\ \mathrm{P}_{\text {out }} & \text { Output power }(\mathrm{W}) \\ \eta_{\text {isentropic }} & \text { Isentropic efficiency }(\%)\end{array}$

optimization. These economic parameters are compared with previous relevant researches. Best economically feasible CSP-biomass power plant configuration is identified by the comparative and sensitivity analysis. Through a comparative analysis this work also illustrates a potential pathway that could qualify the hybrid CSP-biomass-TES power plant as an economically viable option.

\subsection{Previous work}

"Thermosolar Borges", the only hybrid CSP-biomass power plant operating currently, is located in Llieda, Spain, where the average DNI ranges from $1600 \mathrm{kWh} / \mathrm{m}^{2}$ to $1800 \mathrm{kWh} / \mathrm{m}^{2}$ for an average of eight hours each day in summer [15]. Spain's fifty other stand-alone CSP plants are located where the DNI greater than $1900 \mathrm{kWh} / \mathrm{m}^{2}$ for eight hours per day [16].

The modularity of parabolic trough collectors is suited for inclusion in hybrid power generation systems [17]. For a given DNI, outlet temperatures of a parabolic trough collector depend on the heat transfer fluid (HTF) employed; being approximately $400{ }^{\circ} \mathrm{C}$ for thermal oil, $550{ }^{\circ} \mathrm{C}$ for molten salt and $500{ }^{\circ} \mathrm{C}$ for pressurized steam [18]. Solar tower and linear Fresnel concentrating solar collectors are alternative solar concentration options for hybridization with biomass or thermal energy storage systems [19].

Biomass burnt with oxygen from the air releases stored chemical energy as heat to produce steam to drive turbines that produce electricity [20]. Biomass combustion is suitable for both small and largescale power plants. Large-scale biomass power plants are either (i) fixed bed with underfeed stoker and fixed or moving grate, (ii) fluidised bed with bubbling and circulating fluidised bed or (iii) entrained flow or dust combustor to convert energy from biomass [21]. Biomass combustion is a mature technology widely deployed in the power generation industry. However, biomass gasification produces better system efficiencies at large scale [22].

Two-tank molten salt storage consists of two tanks filled with molten salt at different temperature and fill levels. A typical molten salt consists $60 \% \mathrm{NaNO}_{3}$ and $40 \% \mathrm{KNO}_{3}$, known as "solar salt" [23]. With a heat capacity of $1530 \mathrm{~J} \mathrm{~kg}^{-1} \mathrm{k}^{-1}$, molten salt is used as a TES because it is in liquid form between 260 and $550{ }^{\circ} \mathrm{C}$ [24]. Molten salt travels through a heat exchanger at a high temperature to pass heat to a heat transfer fluid that flows in a steam generating system from which superheated steam drives the turbines to produce electricity [25].

With a comparatively low cost, solar salt can also be used as heat transfer fluid with limited energy density because of its fluid properties at atmospheric pressure and operating temperatures which are compatible with high pressure and high temperature steam turbines. A phase change materials or thermochemical TES could have higher energy density than molten salt, but remain under development [26].

Bai et al. [27] evaluated CSP-biomass hybrid power system thermodynamic and economic performances where it was found that the net solar-to-electricity conversion efficiency for a hybrid CSP-biomass power plant was improved by approximately 13 whereas The LCOE drops from $€ 0.17 / \mathrm{kWh}(\sim \$ 0.192 / \mathrm{kWh})$ to $€ 0.069 / \mathrm{kWh}(\sim \$ 0.077 /$ $\mathrm{kWh}$ ), when compared to a typical parabolic trough solar power plant. The biomass fuel consumption is $22.53 \%$ lower than a typical standalone biomass power plant.

A techno-economic benefits of biomass retrofit for concentrated solar power (CSP) organic Rankine cycle (ORC) power plants in three approaches has been investigated by Oyekale et al. [28], where the ORC was supplied constant thermal energy from biomass. In the modular approach of hybrid CSP-biomass power plant, biomass only supplies the balance of thermal energy after solar energy. With TES, it was found that although net-electrical efficiency is higher in a hybrid CSP-biomass-TES power plant, the LCOE of the hybrid CSP-biomass without TES was approximately 23-29\% lower.

Pantaleo et al. [29] investigated a hybrid CSP-biomass power plant in three different locations with a heat recovery system from the exhaust of externally fired gas turbine via TES. A two tank molten salt heat storage was considered. The LCOE of the hybrid CSP-biomass-TES was found to be lowest when TES were sized for $6 \mathrm{~h}$ and $12 \mathrm{~h}$ respectively for single and double collector line configurations due to the trade-off between higher investment cost and thermal energy production rate.

TRNSYS had been used in previous studies to analyse solar PV and CSP systems [30,31]. A steady-state direct steam generation (DSG) model in TRNSYS has been studied by Biencinto et al. [31] that analysed thermal and hydraulic behaviour of a loop of parabolic-trough collectors using TRNSYS data reader for generic data files (Type 9) and solar radiation processor (Type 16). When compared with experimental test data from the 'DISS $2500 \mathrm{~kW}$ test loop' in Plataforma Solar de Almeria, Spain, the model achieved accuracies ranging from $8 \%$ to $27 \%$ [31].

Ibanez et al. [32] found simulation of a high temperature thermal storage in TRNSYS deviated by approximately $2 \%$ from the experimental results. Flores and Franilena [33] simulated a $1000 \mathrm{~kW}$ CSPbiomass-TES power plant in Puglia, Italy using system advisor model (SAM) and TRNSYS. The SAM and TRNSYS results deviated $2.2 \%$ for annual gross electrical power production, $7.8 \%$ for annual net electrical power output and $31.6 \%$ for the efficiency.

\section{System modelling}

Three different Rankine cycle power plant systems are simulated in TRNSYS 17:

- stand-alone biomass;

- hybrid CSP-biomass; and

- hybrid CSP-biomass-TES.

A stand-alone system is simulated to obtain biomass fuel costs over a 20 year of plant operating period to produce an indicative fuel consumption by the power plant. A hybrid CSP-biomass power plants along with another hybrid CSP-biomass power plant with solar-TES are 
simulated to enable comparison of fuel consumption for the same electrical power output. Fuel costs are combined with (i) initial capital expenditure, (ii) capacity factor, (iii) discount rate, and (iv) fixed and variable costs to calculate an LCOE for each of the three power plant systems. The LCOEs of these three power plants are compared through a parametric analysis where capacity factor, capital cost and discount rates are varied.

The design parameters of the hybrid CSP-biomass-thermal energy storage power plant considered are shown in Table 1.

The solar-field consisting of single axis tracking parabolic trough (PT) solar collector has a $36,660 \mathrm{~m}^{2}$ of total aperture area. The inner diameter of absorber tube of each PT collector is $0.07 \mathrm{~m}$ with a focal distance of $1.8 \mathrm{~m}$. The inlet and outlet thermal fluid temperatures from the solar field are set to be $90{ }^{\circ} \mathrm{C}$ and $395{ }^{\circ} \mathrm{C}$ respectively. The biomass system is assumed to include a steam boiler operating at $65 \%$ combustion efficiency from which steam at an outlet pressure of $10,000 \mathrm{kPa}$ enters the turbine shaft. The capacity of the power block is set to be $4000 \mathrm{~kW}$. The outlet enthalpy is given by [34]:

$h_{\text {out }, \text { actuale }}=h_{\text {in }}-\eta_{\text {isentropic }}\left(h_{\text {in }}-h_{\text {out,ideal }}\right)$

where, $h_{\text {in }}$ is the enthalpy of steam entering a given stage of the turbine, $\mathrm{h}_{\text {out,ideal }}$ is enthalpy of steam exiting a given stage of the turbine assuming an isentropic expansion process and $\eta_{\text {isentropic }}$ is isentropic efficiency of the turbine. The power produced by the turbine is;

$W=m_{\text {in }}\left(h_{\text {in }}--h_{\text {out }, \text { actual }}\right)$

where, $\mathrm{W}$ is the work performed during expansion in a given turbine stage, $m_{\text {in }}$ is the mass flow rate of steam entering a given stage of the turbine, and $h_{\text {out,actual }}$ is the enthalpy of steam exiting a given stage of the turbine assuming an isentropic expansion process.

The part load ratio (PLR) is given by [34]:

$P L R=\frac{P_{\text {in }}}{C a p}$

where, Cap is the capacity of the electric generator. Using PLR, the efficiency of the generator is read from a user-supplied data file. The output power is then calculated from:

$P_{\text {out }}=\eta P_{\text {in }}$

where, $\mathrm{P}_{\text {in }}$ is the input power at generator shaft, $\mathrm{P}_{\text {out }}$ is the output electrical power and $\eta$ is the generator efficiency.

For a stand-alone power generation, a biomass steam boiler is connected to a power block comprised of a turbine and an electricity generator as shown in Fig. 1.

In a hybrid CSP-biomass configuration, a biomass power plant is operated with a parabolic trough solar collector that provides thermal energy during the day. Heated fluid from the solar field is fed into a steam generator that produces steam. This steam directly enters to the biomass steam boiler to maintain the steam temperature. The biomass system in this case is assumed to only operate if the solar energy system is unable to produce rated thermal energy. A partial image of TRNSYS 17 deck file for a hybrid CSP-biomass power plant with 6 rows of the solar field is presented in this Fig. 2.

The TRNSYS 17 simulation diagram with a heat storage, integrated into a CSP-biomass system is shown in Fig. 3. The fully-mixed storage tank is connected to the steam generator via an integrated heat exchanger to provide four hours of additional thermal energy. A $5 \mathrm{~m}$ tall tank with a volume of $769 \mathrm{~m}^{3}$ is assumed to contain a salt storage fluid of density $1850 \mathrm{~kg} / \mathrm{m}^{3}$ and thermal conductivity of $0.0055 \mathrm{~W} / \mathrm{m} .{ }^{\circ} \mathrm{C}$. The storage system is designed to provide thermal energy required for the turbine to produce $4000 \mathrm{~kW}$ of electricity for $4 \mathrm{~h}$.

Weather data for Barajas Airport, Madrid, (TRNSYS weather model ES-Madrid-Barajas-82210) are used. Inlet and outlet working fluid temperatures for a single parabolic trough loop are $90{ }^{\circ} \mathrm{C}$ and approximately $395{ }^{\circ} \mathrm{C}$ respectively. All simulated power systems are designed to produce $4000 \mathrm{~kW}$ electric power output. A pre-validated
TRNSYS solar field model consisting 26 rows of Type 1257 parabolic trough solar collectors is used [34].

To simulate a hybrid power plant, the heated thermal fluid is assumed to be supplied to a Type 636 heat recovery steam generator. High pressure steam is supplied to a Type 638 biomass steam boiler that processes user-specified steam outlet condition. The overall boiler efficiency is set to $75 \%$. To calculate the required fuel consumption, the steam input energy is divided by the boiler efficiency. This data is then supplied to a Type 582 economic analysis component to estimate the plant lifecycle fuel cost of 20 years.

The outlet steam is assumed to run a Type 592 steam turbine. This component works on an isentropic efficiency approach to calculate the performance of the steam turbine. The input parameters are the steam inlet conditions and the turbine exhaust pressures. The turbine provides the rated rotation into the spinning input shaft of a Type 599 electrical generator. The model calculates the part-load ratio of the device by the generation capacity along with the input shaft power. This part-load ratio is used to obtain the output power and thermal energy losses. To simulate a hybrid CSP-biomass-TES power plant, the heated fluids from the solar field is assumed to be supplied to a Type 60 stratified liquid storage tank. The thermal energy storage is connected to a Type 636 heat recovery steam generator that maintain specified steam outlet conditions.

\subsection{Simulation results}

An official price for the biomass fuel in Spain is unavailable as they do not constitute a representative resource of energy [35]. The biomass fuel price is approximated by a comparative biomass price data with Ireland. In 2017 the biomass wood cheap price was found to be €0.03/ kWh [36]. In a different research, Keränen et al. [37] found that the price of biomass was approximately $30 \%$ lower than the price in Ireland. Considering the volatility of the biomass fuel price, this study

Table 1

Hybrid CSP-biomass-TES plant parameters.

\begin{tabular}{|c|c|c|}
\hline Site & Power plant land area & 19 ha \\
\hline & -Solar collector type & Parabolic trough \\
\hline \multirow[t]{13}{*}{ Solar Energy Collection } & $\begin{array}{l}\text { Solar collectors in each } \\
\text { row }\end{array}$ & 26 \\
\hline & Number of rows & 6 \\
\hline & Collector length & $47 \mathrm{~m}$ \\
\hline & Collector aperture width & $5 \mathrm{~m}$ \\
\hline & $\begin{array}{l}\text { Inner diameter of } \\
\text { absorber tube }\end{array}$ & $0.07 \mathrm{~m}$ \\
\hline & Focal length for collector & $1.8 \mathrm{~m}$ \\
\hline & Collector tracking & Single axis \\
\hline & Annual average solar & $1600 \mathrm{kWh} / \mathrm{m}^{2}$ \\
\hline & DNI & \\
\hline & HTF type & $\begin{array}{l}\text { Ethylene Glycol based } \\
\text { water solutions }\end{array}$ \\
\hline & HTF fluid density & $1074 \mathrm{~kg} / \mathrm{m}^{3}$ \\
\hline & Inlet fluid temperature & $90{ }^{\circ} \mathrm{C}$ \\
\hline & Outlet fluid temperature & $395{ }^{\circ} \mathrm{C}$ \\
\hline \multirow[t]{2}{*}{ Thermal Energy Process } & Turbine inlet pressure & $10,000 \mathrm{kPa}$ \\
\hline & Combustion efficiency & $70 \%$ \\
\hline \multirow[t]{7}{*}{ Thermal Energy Storage } & TES discharging time & $\sim 4 \mathrm{~h}$ \\
\hline & TES tank volume & $769 \mathrm{~m}^{3}$ \\
\hline & TES type & NaNO3- KNO3 salt \\
\hline & TES fluid density & $1850 \mathrm{~kg} / \mathrm{m}^{3}$ \\
\hline & thermal conductivity & $0.0055 \mathrm{~W} / \mathrm{cm} .{ }^{\circ} \mathrm{C}$ \\
\hline & Specific heat capacity & $2660.19\left(\mathrm{~J} / \mathrm{kg}{ }^{\circ} \mathrm{C}\right)$ \\
\hline & Freezing/Melting point & $222{ }^{\circ} \mathrm{C}$ \\
\hline \multirow[t]{3}{*}{ Power Block } & $\begin{array}{l}\text { Plant nameplate } \\
\text { capacity }\end{array}$ & $4000 \mathrm{~kW}$ \\
\hline & Generator efficiency & $95 \%$ \\
\hline & Capacity factor & $90 \%$ \\
\hline
\end{tabular}




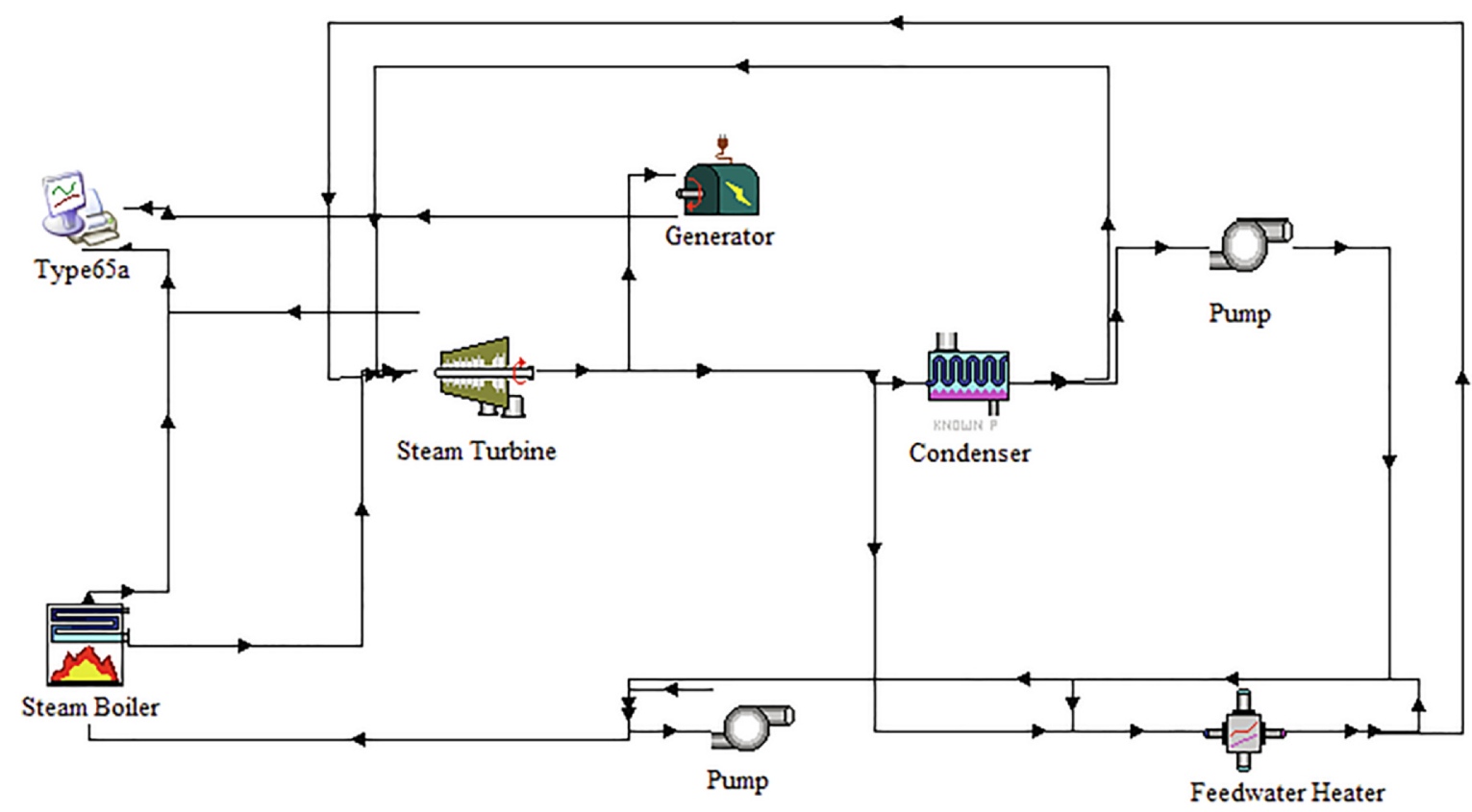

Fig. 1. Biomass system TRNSYS block diagram.

considered the price to be approximately $€ 0.025 / \mathrm{kWh}$.

The stand-alone biomass configuration shows a constant consumption of biomass fuel while electric power is being generated. Electricity is produced by two energy sources in a hybrid CSP-biomass power plant as shown in Fig. 4. The left axis represents the biomass thermal input energy required for the power plant, whereas the solar collector outlet thermal energy is represented in right axis. A simulation time series of
$168 \mathrm{~h}$ is set in this study. The biomass input energy is only used at night when there is no solar energy as shown in Fig. 4. Average useful solar thermal energy is supplied to the plant for eight hours each day during the daylight hours as shown on the right axis of Fig. 4, requiring approximately $26 \%$ less biomass fuel consumption. This is similar to the results presented in previous work where a reduction of a $22.53 \%$ biomass fuel consumption was found for a hybrid CSP-biomass power

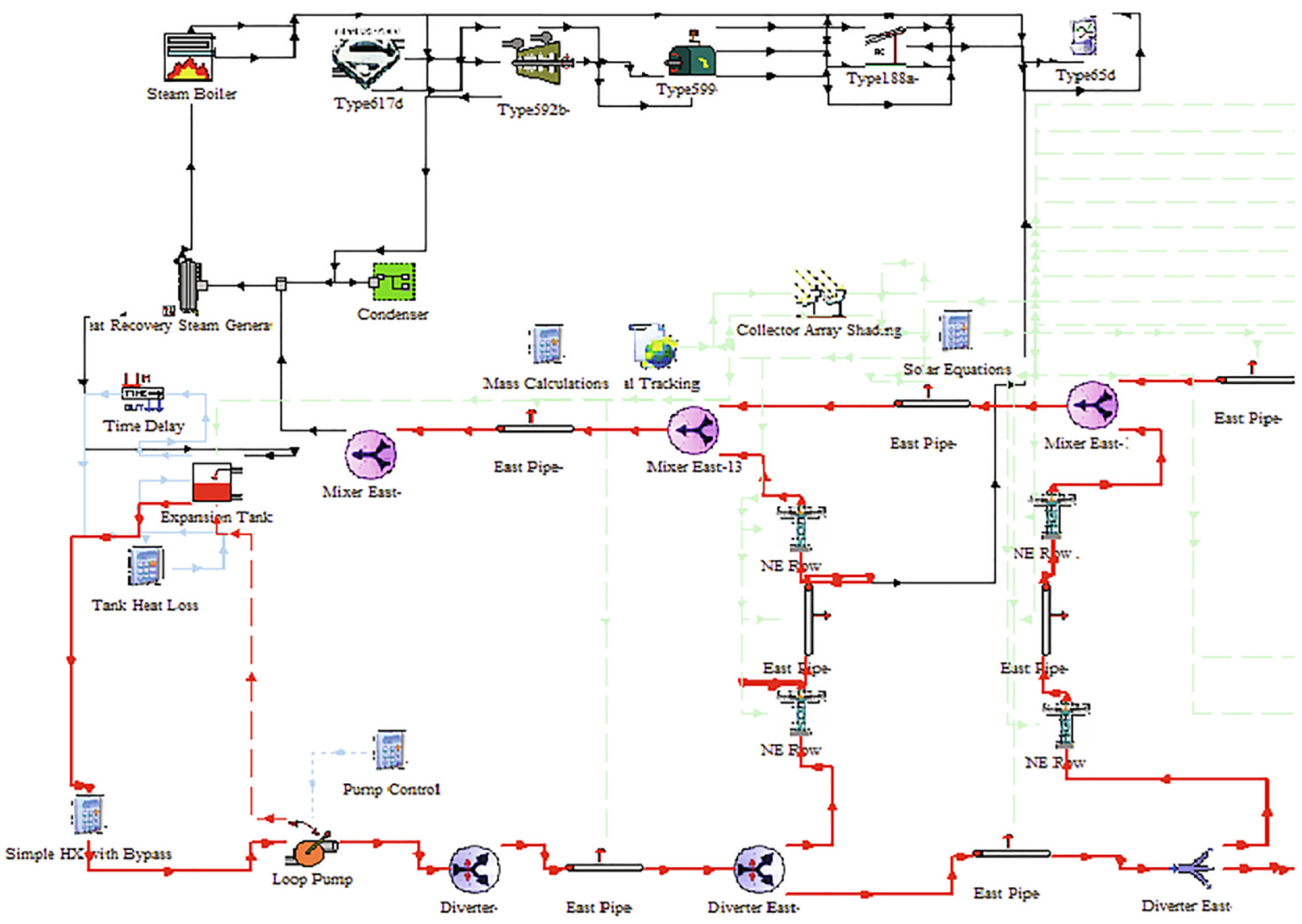

Fig. 2. CSP-biomass system TRNSYS block diagram. 


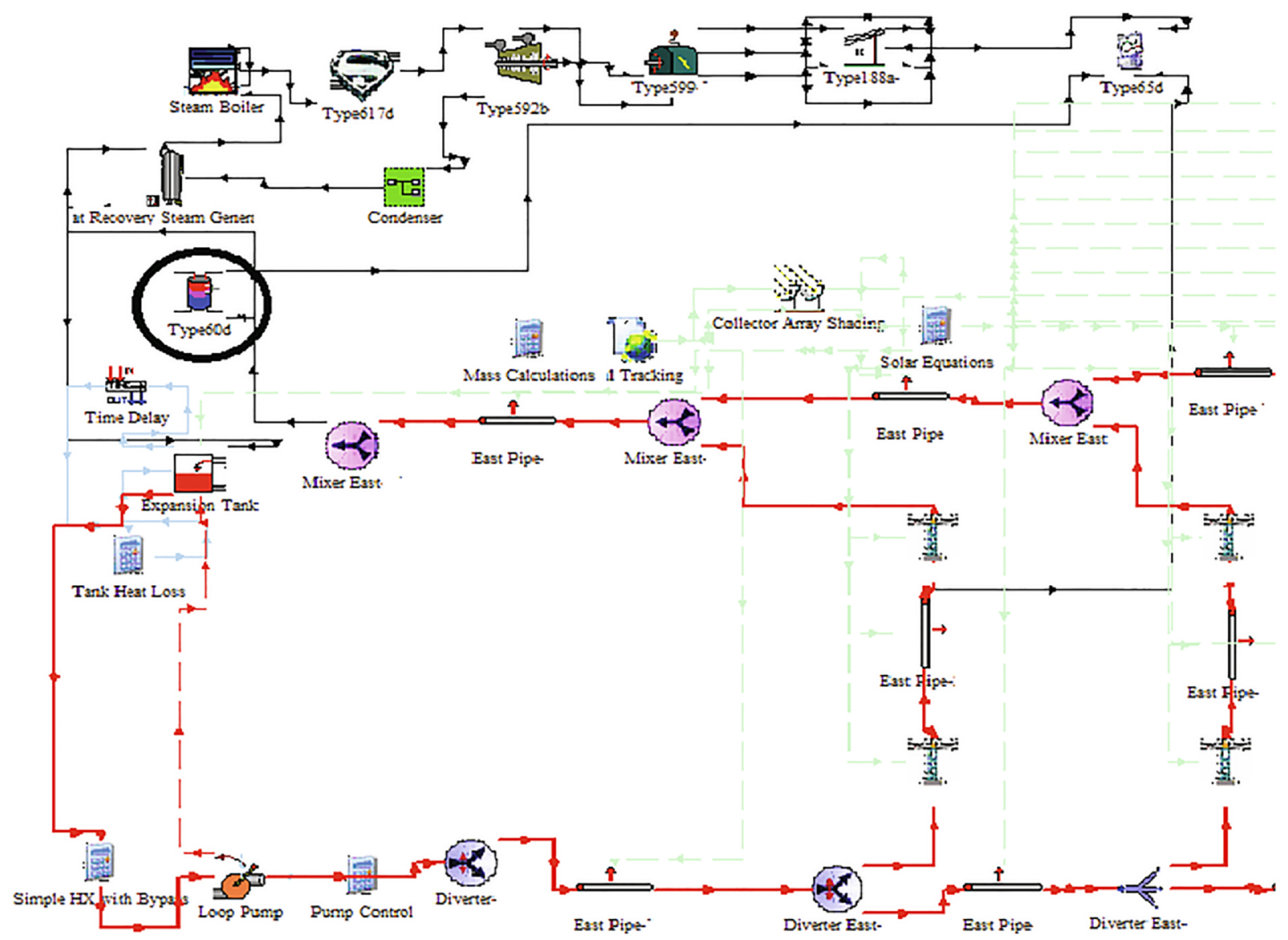

Fig. 3. CSP-biomass -TES system block diagram.

plant [27].

For a hybrid CSP-biomass-TES systems, the solar collector outlet thermal energy, required biomass thermal input energy are presented in the left-hand axis and average internal temperature of TES is presented in the right-hand axis of Fig. 5. Optimal biomass thermal input energy of $6500 \mathrm{~kW}$ is used only at the initial plant run time (up to 14th hr). After that required biomass thermal input energy is less than $5000 \mathrm{~kW}$.

The solar field starts generating thermal energy at approximately 10th hour. However, the biomass unit was not immediately turned off in the initial hours, as solar energy is used to increase the TES temperature to a set-point of $385{ }^{\circ} \mathrm{C}$ (right axis of Fig. 5) before being used to generate electricity. Therefore, solar energy is not utilized to generate electricity during the initial period of a day. The biomass fuel consumption continues for a longer period of time for simulated 7 days as shown in Fig. 5 when compared with Fig. 4. This potentially increases overall biomass fuel expenditure.

There is a significant biomass fuel input reduction is observed as illustrated in Figs. 4 and 5 when either CSP or CSP-TES is combined

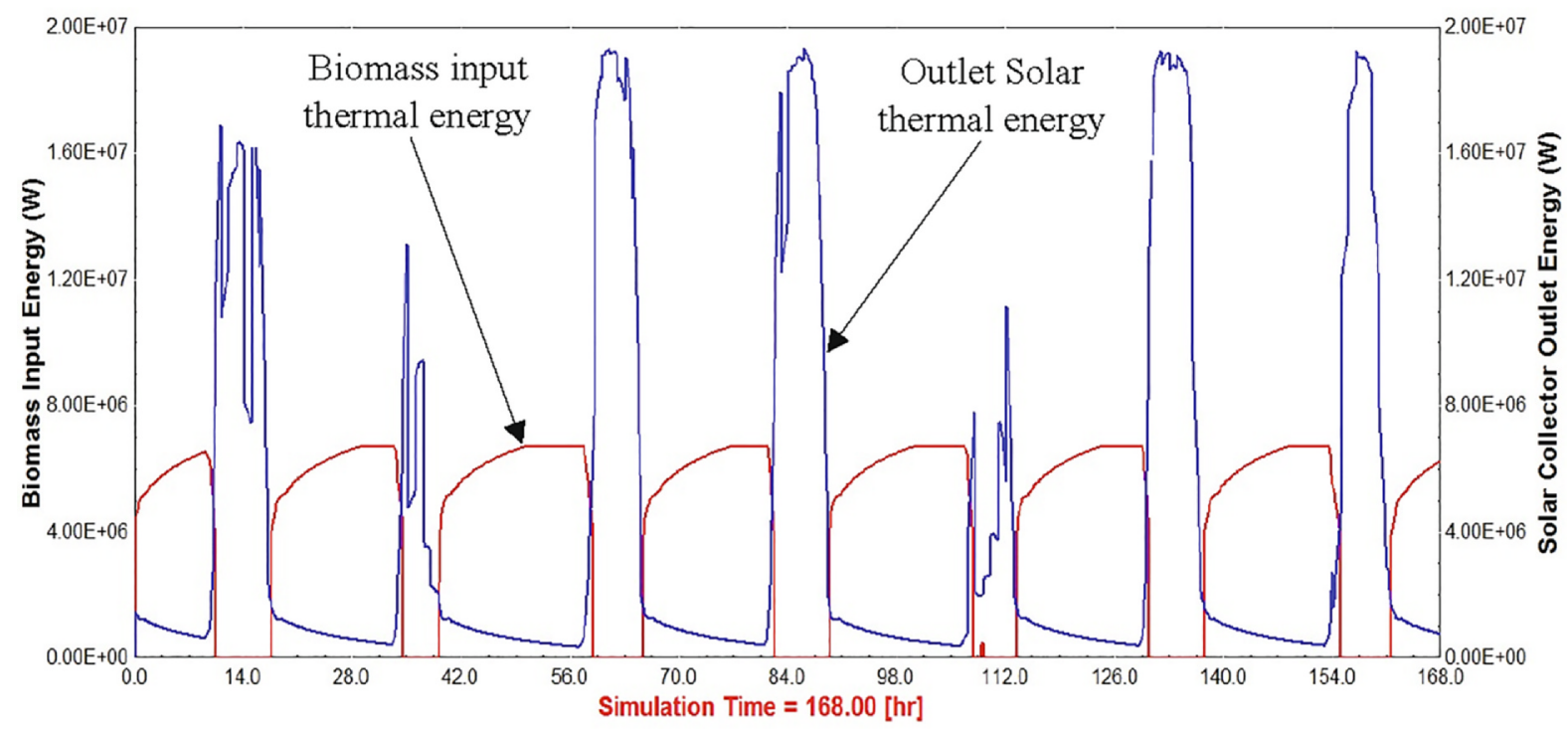

Fig. 4. TRNSYS simulation output of CSP-biomass system. 


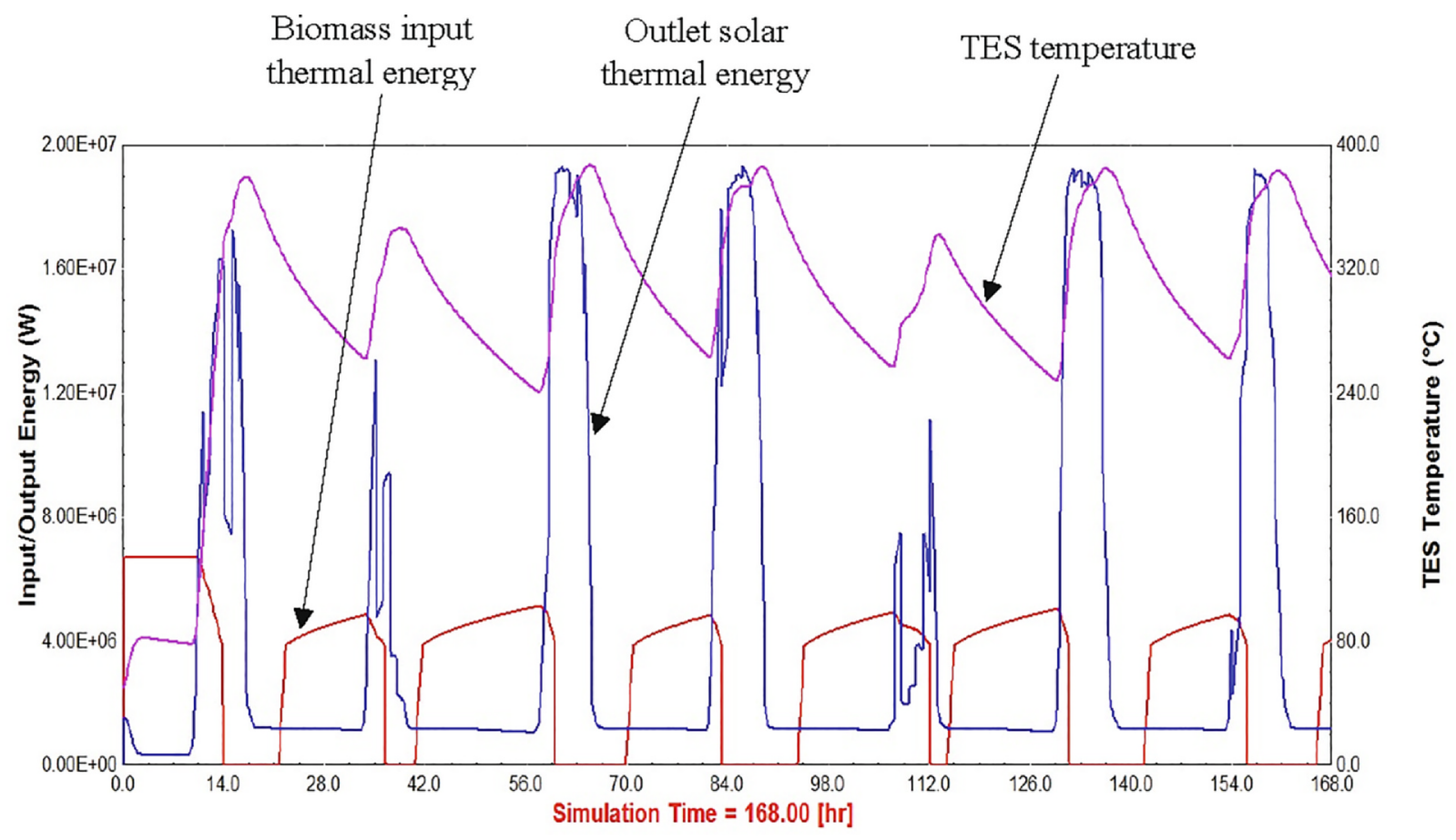

Fig. 5. CSP-biomass-TES power plant.

with a biomass power plant. It was found that, the temperature of the HTF is constant at $336{ }^{\circ} \mathrm{C}$ for stand-alone biomass power plant. In solarbiomass power plant the maximum temperature could be obtained up to $390{ }^{\circ} \mathrm{C}$ in active solar period for an average $8 \mathrm{~h}$. That produces a mean HTF temperature of $345{ }^{\circ} \mathrm{C}$ for solar-biomass and solar-biomassTES power plants as shown in Table 2. The solar fraction for hybrid CSP-biomass-TES is approximately $6 \%$ higher than that of hybrid CSPbiomass power plant. Approximately $1.0 \%$ higher electricity output is generated from solar-biomass and solar-biomass-TES configurations when compared to stand-alone biomass power plant.

\section{Economic analysis}

The cumulative biomass fuel consumptions for three types of power plants are shown in Fig. 6. In this simulation the biomass fuel consumption for 7 days ( $168 \mathrm{~h}$ ) has been extrapolated to a cumulative fuel expenditure for 20 years of plant lifetime. A stand-alone biomass power plant requires a continuous fuel consumptions with full plant capacity load. Therefore, among these three simulated systems, the life cycle fuel cost is higher for a stand-alone biomass power plant. At a rate of $€ 0.025 / \mathrm{kWh}$, the life cycle operational fuel cost of a stand-alone biomass power plant is found to be $€ 14.2$ Million (M) for 20 years as shown in Fig. 6. In contrast, the fuel cost curve of the hybrid CSP-biomass power plant only increases when biomass combustion unit operates with a $70 \%$ biomass fraction. There is obviously no biomass cost during the days when only solar energy is used. In a hybrid CSP-biomass power plant, cumulative fuel cost of $€ 10.5 \mathrm{M}$ for a 20 year plant life gives a $26 \%$ reduction of biomass fuel expenditure. Although the hybrid CSPbiomass with TES systems does not offer a significant fuel savings compared to a hybrid CSP-biomass power plant, it produces the lowest life cycle fuel expenditure with a cumulative fuel cost of $€ 10.2 \mathrm{M}$ over 20 years, a $28 \%$ reduction compared to a stand-alone biomass power plant.

Due to biomass fuel use in initial solar hours, the integration of TES with CSP-biomass system does not significantly reduce costs compared to a CSP-biomass hybrid power plant. Integration of TES reduces overall biomass fuel consumptions, but the operating time of biomass combustion unit increases due to the time required for the solar energy system to heat the thermal fluid. Thus, the fuel expenditure is only $2.6 \%$ less than the hybrid CSP-biomass power plant. This is due to better utilization of solar energy, instead of dumping excess solar energy collected during peak solar radiation periods, it is stored for later use.

All power plant configurations are simulated to obtain the biomass fuel cost for an operational period of 20 years as illustrated in Fig. 6 . Calculated fuel costs are then combined with (i) discount rate, (ii) initial capital cost, (iii) capacity factor, and (iv) fixed and variable cost to obtain a levelized cost of electricity (LCOE) for the three power plants. LCOE is the net present value of the unit-cost of electricity over the lifetime of a generating asset. LCOE is sensitive to the plant investment costs and, discount rate, fixed and variable operations cost [38]. This study assumed fuel costs over the plant operational period (obtained from simulation) as a fixed cost. Variable costs are associated with plant maintenance and overhaul. LCOE is given by:

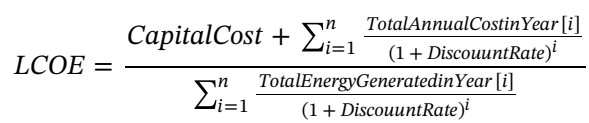

where, ' $n$ ' is the expected lifetime of the power plant and ' $i$ ' is number of years.

The LCOE tool developed by the King Abdullah Petroleum Studies and Research Center are used [39].

\subsection{Cost estimation}

Average indicative capital expenditure (CAPEX) for a stand-alone

Table 2

System performance parameters of three power plant configurations.

\begin{tabular}{|c|c|c|c|}
\hline & Biomass & $\begin{array}{l}\text { Solar- } \\
\text { Biomass }\end{array}$ & $\begin{array}{l}\text { Solar-Biomass- } \\
\text { TES }\end{array}$ \\
\hline Mass flow rate of $\mathrm{HTF}(\mathrm{Kg} / \mathrm{s})$ & 0.28 & 0.28 & 0.28 \\
\hline HTF temperature $\left({ }^{\circ} \mathrm{C}\right)$ & 336 & 345 & 345 \\
\hline $\begin{array}{l}\text { Overall solar thermal-to-electricity } \\
\text { conversion efficiency (\%) }\end{array}$ & - & 22 & 25 \\
\hline Electricity output $(\mathrm{kW})$ & 3849 & 3868 & 3861 \\
\hline
\end{tabular}




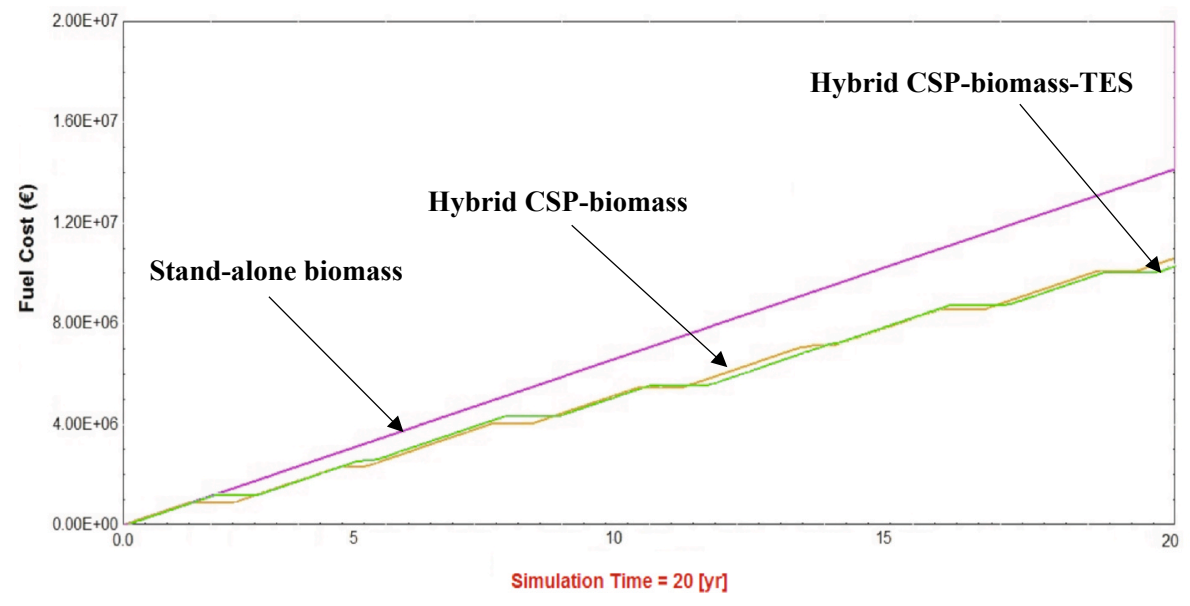

Fig. 6. Cumulative fuel costs of different systems.

biomass power plant has been found to be approximately $€ 3500 / \mathrm{kW}$ [40], where the fixed cost being typically $4 \%$ of the initial capital cost [41]. An annual biomass fuel cost of $€ 175 / \mathrm{kW}$ is obtained from simulation results. A detailed cost analysis of CSP power plants has been presented in the relevant previous literature [42], where the installed cost of a stand-alone CSP power plant with parabolic trough concentrator has found to be dropped from $€ 4100 / \mathrm{kW}$ in 2012 to $€ 3000$ $/ \mathrm{kW}$ in 2016 [43]. Assuming core system component sharing for a thermal power plant, the initial capital investment cost of a hybrid CSPbiomass power plant has been estimated to be $€ 6000 / \mathrm{kW}$ [40]. A cumulative fixed cost of a hybrid CSP-biomass power plant is calculated from (i) $2 \%$ of investment cost of biomass system and (ii) $€ 0.01 / \mathrm{kWh}$ for a CSP system [43]. Compared to the stand-alone biomass power plant, the simulated annual biomass fuel consumption of a hybrid CSPbiomass power plant is reduced to $€ 132 / \mathrm{kW}$. For a hybrid CSP-biomass-TES system the initial capital investment cost is estimated to be $€ 8000 / \mathrm{kWh}$ [44]. The integration of TES into a hybrid CSP-biomass power generation system has a cost of $€ 2000 / \mathrm{kW}$ [45]. Fixed maintenance costs are the sum of (i) $2 \%$ of biomass unit and [46], (ii) $€ 0.02$ $/ \mathrm{kWh}$ cost for the solar and TES systems [47]. Simulated annual biomass fuel consumption for hybrid CSP-biomass - TES power plant is $€ 127 / \mathrm{kW}$. A 9\% discount rate for all power plant configurations with a $2 \%$ overall cost escalation are used. The choice of a $9 \%$ discount rate influences overall viability, but does not alter the ranking of different system configurations. The parameters of all power plants are presented in Table 3.

The stand-alone biomass power plant has the lowest LCOE of $€ 0.120 / \mathrm{kWh}$. The hybrid CSP - biomass and hybrid CSP - biomass-TES have LCOE $0.140 / \mathrm{kWh}$ and $0.180 / \mathrm{kWh}$ respectively. The base-case LCOE of the hybrid CSP - biomass power plant is found to be approximately $17 \%$ higher than the base-case LCOE of stand-alone biomass power plant, whereas the base-case LCOE of the hybrid CSP biomass-TES are approximately $50 \%$ and $28 \%$ higher when compared to stand-alone biomass and hybrid CSP - biomass power plant base-case LCOE respectively.

\subsubsection{Comparison with previous studies}

LCOE of three different power plant configurations, obtained from TRNSYS 17 simulation, are compared with the literature. Pantaleo et al. [29] found that the LCOE of the hybrid CSP-biomass power plant is higher than a stand-alone biomass power plant in three different locations in Priolo, Marseilles and Rabat. The study showed the LCOE ranges from $€ 0.100 / \mathrm{kWh}$ to $€ 0.170 / \mathrm{kWh}$ for a stand-alone biomass power plant configuration with different biomass fuel costs. In this study the LCOE for a stand-alone biomass power plant is found to be $€ 0.12 / \mathrm{kWh}$ for Llieda Spain. Oyekale et al [28] presented LCOE for five modular hybrid CSP-biomass-TES configurations. Two configurations having no TES integration with one being $70 \%$ of biomass fraction and the other with $60 \%$. Other three configurations included $1.3 \mathrm{~h}, 2.3 \mathrm{~h}$ and $3.4 \mathrm{~h}$ of TES integrated CSP-biomass power plant with rated plant capacity less than $1 \mathrm{MW}$. The results of $70 \%$ biomass fraction with no TES (Modular CSP-biomass) is compared with presented hybrid CSP biomass power plant in Fig. 7. The plant with $3.4 \mathrm{~h}$ of TES configuration (Modular CSP-biomass-TES-3.4hr) is also compared with presented hybrid CSP-biomass-TES power plant due to their close nature of configuration (Fig. 7). The system performance of biomass retrofitted for the real Ottana plant configuration (Ottana CSP-biomass-TES-4.9hr) was also evaluated in the same study [28] where the TES capacity was set to $4.9 \mathrm{~h}$.

As can be seen in Fig. 7, the LCOEs of the 'Modular CSP-biomassTES-3.4hr' [28] and presented hybrid CSP-biomass power plant are $€ 0.130 / \mathrm{kWh}$ and $€ 0.140 / \mathrm{kWh}$ giving approximately $7 \%$ difference. The LCOEs of 'Modular CSP-biomass-TES-3.4hr' are $€ 0.146 / \mathrm{kWh}$, whereas $€ 0.180 / \mathrm{kWh}$ for presented hybrid CSP-biomass-TES power plant. The highest $20.8 \%$ difference is due to the TES sizing of these two studies, presented hybrid CSP-biomass-TES power plant being 16.2\% larger than the other 'Modular CSP-biomass-TES-3.4hr' and the higher biomass fuel price assumption in different jurisdictions. When LCOE of presented hybrid CSP-biomass-TES power plant is compared with the 'Ottana CSP-biomass-TES-4.9hr' model presented in [28] with $50 \%$ of biomass fraction and $4.9 \mathrm{~h}$ of TES, it is found the LCOE of 'Ottana CSPbiomass-TES-4.9hr' is $€ 0.178 / \mathrm{kWh}$, which is $1.1 \%$ lower than the LCOE of presented hybrid CSP-biomass-TES as shown in Fig. 7.

\subsubsection{Sensitivity analysis}

A sensitivity analyses are performed by varying key parameters such as (i) capital expenditure, (ii) discount rate and (iii) capacity factor as

Table 3

Economic parameters of different CSP-biomass power plants.

\begin{tabular}{llll}
\hline & Biomass & CSP-Biomass & $\begin{array}{l}\text { CSP-Biomass- } \\
\text { TES }\end{array}$ \\
\hline Capex $(€ / \mathrm{kW})$ & 3500 & 6000 & 8000 \\
Annual fuel cost $(€ / \mathrm{kW})$ & 175 & 132 & 127 \\
Annual fixed operating cost $(€ / \mathrm{kW})$ & 140 & 160 & 240 \\
\hline Annual O\&M cost $(€ / \mathrm{kW})$ & 50 & & \\
O\&M cost escalator & $2 \%$ & & \\
Fuel cost escalator & $2 \%$ & & \\
Discount rate $(\%)$ & $9 \%$ & & \\
Capacity Factor $(\%)$ & $85 \%$ & & \\
Plant capacity (kW) & 4000 & & \\
Plant lifetime (Years) & 20 & & \\
\hline
\end{tabular}




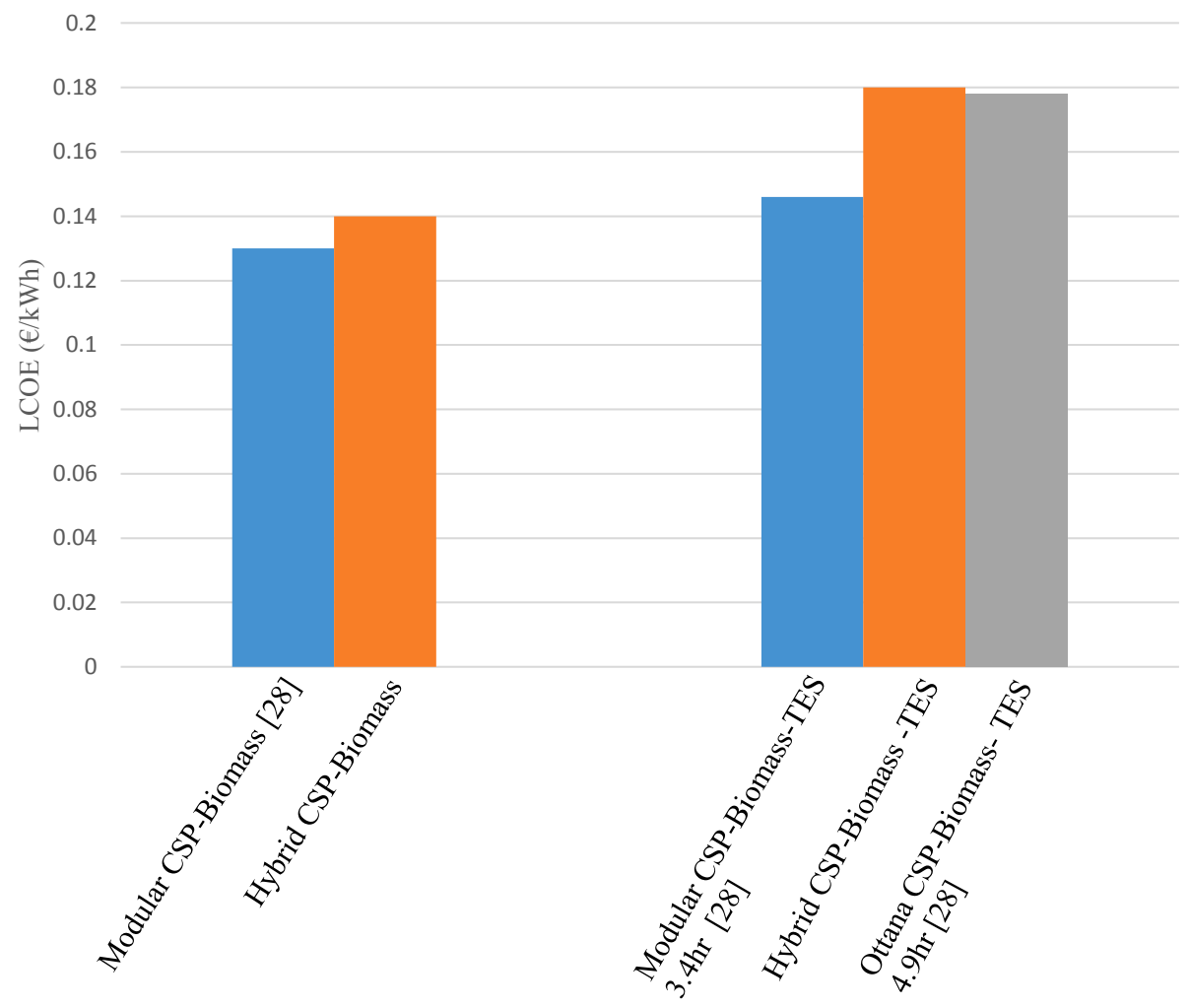

Fig. 7. LCOE comparisons between presented work and relevant previous research.

presented in the Table 4. The column 'Base-case' presents the LCOE obtained from the model as described in section 3.1. The column 'Upper limit' and 'Lower limit' provide a realistic maximum and minimum ranges of LCOE respectively when techno-economic parameters (i.e. capacity factor, discount rate and capital costs) are varied.

It is found that varying the capital cost and capacity factor by $10 \%$ does not affect the LCOE as it is found when $5 \%$ of discount rate is varied (from lower limit $4 \%$ to upper limit 14\%). A variation of $5 \%$ discount rate changes a hybrid CSP-biomass power plant base-case LCOE of $0.14 / \mathrm{kWh}$ from a lower limit of $0.112 / \mathrm{kWh}$ to an upper limit of $0.169 / \mathrm{kWh}$. This produces the lower limit (with a discount rate $14 \%$ ) of a hybrid CSP-biomass power plant LCOE to be competitive with the base-case LCOE $(0.12 / \mathrm{kWh})$ of the stand-alone biomass system (with discount rate $9 \%$ ).

The presented hybrid CSP-biomass-TES power plant has the highest LCOE of $0.180 / \mathrm{kWh}$ due to the added initial expenditure for the TES system along with additional TES operating expenditures. However, by increasing the capacity factor by $10 \%$, while reducing capital cost by $10 \%$ improves LCOE for hybrid CSP-biomass-TES power plant by $5 \%$ to 7\% respectively (Table 4). Moreover, a CSP-biomass-TES system produces an LCOE of $0.165 / \mathrm{kWh}$ (approximately $9 \%$ less than $0.180 / \mathrm{kWh}$ ) when $14 \%$ discount rate is applied as shown in Table 4.

As can be seen from the percentage variation in parameters shown in Fig. 8, a 5\% variation of the discount rate has the highest impact on the LCOE of all power plants. The ranking of different plant configurations has been changed for different economic parameters. For example; discount rate and initial capital cost have the most influence in giving a lower LCOE for hybrid CSP-biomass power plant followed by hybrid CSP-biomass-TES systems and stand-alone biomass power plant. An increment of $10 \%$ capacity factor ranks stand-alone biomass power plant highest (with 5.3\% LCOE reduction) followed by hybrid CSPbiomass (with 5\% LCOE reduction) and hybrid CSP-biomass-TES systems (with a $4.7 \%$ LCOE reduction). Sensitivity analyses indicate that the viability of a new hybrid CSP-biomass-TES power plant depends on the discount rate and initial capital cost.

\section{Conclusion}

In this work, three power plant configurations were modelled and simulated. Simulation results produced cumulative fuel expenditures over 20 years of plant lifetime, from which LCOE was estimated. LCOEs of three configurations were compared with relevant literatures. A

Table 4

Variation of LCOE of different plant configurations.

\begin{tabular}{|c|c|c|c|c|c|c|c|c|c|}
\hline & \multicolumn{3}{|l|}{ Biomass } & \multicolumn{3}{|c|}{ CSP-Biomass } & \multicolumn{3}{|c|}{ CSP-Biomass-TES } \\
\hline & Lower limit & Base-case & Upper limit & Lower limit & Base-case & Upper limit & Lower limit & Base-case & Upper limit \\
\hline Capacity factor (\%) & $90 \%$ & $80 \%$ & $70 \%$ & $90 \%$ & $80 \%$ & $70 \%$ & $90 \%$ & $80 \%$ & $70 \%$ \\
\hline $\mathrm{LCOE}(€ / \mathrm{kWh})$ & 0.108 & 0.120 & 0.120 & 0.126 & 0.140 & 0.154 & 0.171 & 0.180 & 0.189 \\
\hline Discount rate (\%) & $14 \%$ & $9 \%$ & $4 \%$ & $14 \%$ & $9 \%$ & $4 \%$ & $14 \%$ & $9 \%$ & $4 \%$ \\
\hline LCOE (€/kWh) & 0.110 & 0.120 & 0.130 & 0.112 & 0.140 & 0.169 & 0.165 & 0.180 & 0.195 \\
\hline Capital cost $(€ / \mathrm{kW})$ & 3150 & 3500 & 3850 & 5400 & 6000 & 6600 & 7200 & 8000 & 8800 \\
\hline $\mathrm{LCOE}(€ / \mathrm{kWh})$ & 0.108 & 0.120 & 0.119 & 0.130 & 0.140 & 0.147 & 0.168 & 0.180 & 0.191 \\
\hline
\end{tabular}




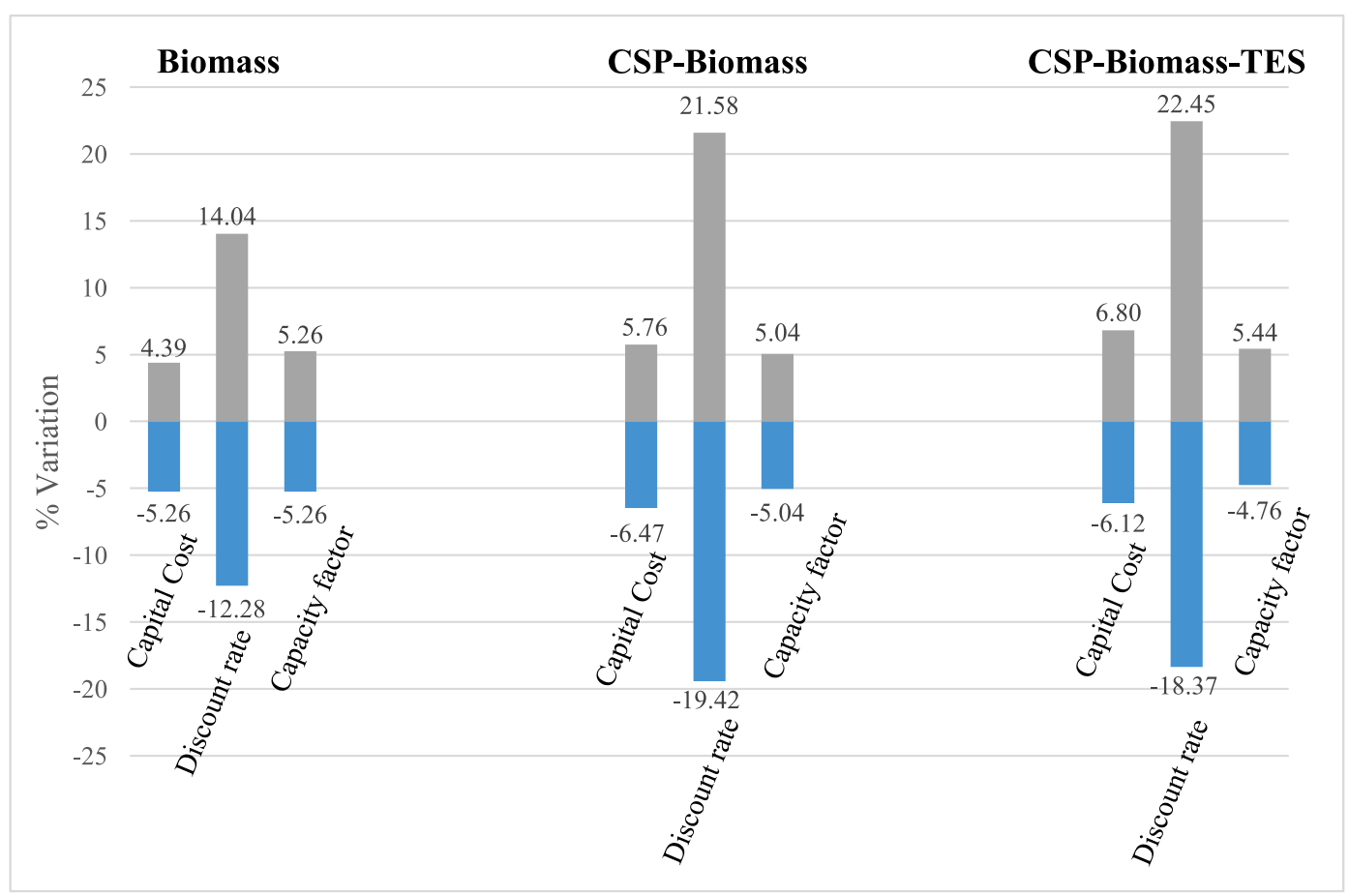

Fig. 8. Percentage variation of LCOE of a different power plant configurations in respect to (i) capital cost, (ii) discount rate and, (iii) capacity factor.

sensitivity analysis was conducted to find the key techno-economic parameters that drive a potential reduction of individual plant's LCOE. The key findings are;

- A hybrid CSP-biomass system produced a considerable $26 \%$ reduction of fuel expenditure compared with a stand-alone biomass power plant.

- Although the biomass fuel consumption is higher in stand-alone biomass power plant, the LCOE was approximately $17 \%$ lower than hybrid CSP-biomass power plant due to the increased initial cost of the solar field.

- A 5\% increment of discount rate could reduce the LCOE of a hybrid CSP-biomass power plant to $€ 0.112 / \mathrm{kWh}$ compared to the LCOE of $€ 0.120 / \mathrm{kWh}$ for the stand-alone biomass power plant.

- Solar energy intermittency restricted a plant performance. When a low DNI was received, the TES was not fully charged during the day. To maintain the simulated rated plant power output the biomass system was operated immediately after the solar period leading to a higher biomass fuel use and expenditure.

- Annual biomass fuel expenditure of a hybrid CSP-biomass power plant with a stratified TES system was only $3.8 \%$ lower than the one without TES as shown in Table 3.

- The sensitivity analysis showed that the base-case LCOE of a hybrid CSP-biomass power plant was approximately $28 \%$ lower than a hybrid CSP-biomass-TES power plant that could be reduced to $17.8 \%$ if an additional $5 \%$ discount rate was imposed.

Although an integration of a TES could extend solar fraction of a hybrid CSP-biomass power plant, the biomass fuel consumption was not significantly reduced when compared to a hybrid power plant without TES. This is due to the nature of the TES operation in this particular power plant configuration during the effective solar energy period as shown by the TRNSYS simulation results. This study shows that varying key techno-economic parameters have significant effects on LCOE reduction in different power plant configurations. A financial incentive/ subsidies can facilitate a new hybrid CSP-biomass-TES power plant for future commercialization.

\section{Declaration of Competing Interest}

The authors declare that they have no known competing financial interests or personal relationships that could have appeared to influence the work reported in this paper.

\section{Acknowledgements}

The authors appreciate the financial support provided by Technological University Dublin under the Fiosraigh research scholarship scheme. This research was supported by MaREI, the SFI Research Centre for Energy, Climate and Marine [Grant No: 121RC12302-P2].

\section{References}

[1] Powell KM, Rashid K, Ellingwood K, Tuttle J, Iverson BD. Hybrid concentrated solar thermal power systems: A review. Renewable Sustain Energy Rev 2017;80:215-37.

2] Oyekale J, Petrollese M, Cau G. Modified auxiliary exergy costing in advanced exergoeconomic analysis applied to a hybrid solar-biomass organic Rankine cycle plant. Appl Energy 2020;268:114888.

[3] Hussain CMI, Norton B, Duffy A. Technological assessment of different CSP-biomass systems for hybrid power generation in Europe. Renew Sustain Energy Rev 2016;68:1115-29.

[4] Pramanik S, Ravikrishna RV. A review of concentrated solar power hybrid technologies. Appl Therm Eng 2017;127:602-37.

[5] Bet Sarkis R, Zare V. Proposal and analysis of two novel integrated configurations for hybrid solar-biomass power generation systems: Thermodynamic and economic evaluation. Energy Convers Manage 2018;160:411-25.

[6] Pantaleo AM, Camporeale SM, Sorrentino A, Miliozzi A, Shah N, Markides CN. Hybrid solar-biomass combined Brayton/organic Rankine-cycle plants integrated with thermal storage: Techno-economic feasibility in selected Mediterranean areas. Renewable Energy 2018:1-19.

[7] Milani R, Szklo A, Hoffmann BS. Hybridization of concentrated solar power with biomass gasification in Brazil's semiarid region. Energy Convers Manage 2017;143:522-37.

[8] Pantaleo AM, Camporeale SM, Miliozzi A, Russo V, Shah N, Markides CN. Novel hybrid CSP-biomass CHP for flexible generation: Thermo-economic analysis and profitability assessment. Appl Energy 2017;204:994-1006.

[9] Roni MS, Chowdhury S, Mamun S, Marufuzzaman M, Lein W, Johnson S. Biomass co- firing technology with policies, challenges, and opportunities: A global review. Renewable Sustain Energy Rev 2017;78:1089-101.

[10] Bellos E, Vellios L, Theodosiou IC, Tzivanidis C. Investigation of a CSP-biomass polygeneration system. Energy Convers Manage 2018;173:283-95.

[11] González-Portillo LF, Muñoz-Antón J, Martínez-Val JM. An analytical optimization 
of thermal energy storage for electricity cost reduction in solar thermal electric plants. Appl Energy 2017;185:531-46.

[12] Wang S, Fu Z. Thermodynamic and economic analysis of solar assisted CCHP-ORC system with DME as fuel. Energy Convers Manage 2019;186:535-45.

[13] Yuan J, Cui C, Xiao Z, Zhang C, Gang W. Performance analysis of thermal energy storage in distributed energy system under different load profiles. Energy Convers Manage 2020;208:112596.

[14] Tapachès E, Salas D, Perier-Muzet M, Mauran S, Aussel D, Mazet N. The value of thermochemical storage for concentrated solar power plants: Economic and tech nical conditions of power plants profitability on spot markets. Energy Convers Manage 2019;198:111078.

[15] Cot A, Amettler A, Vall-Llovera J, Aguilo J, Termosolar Borges AJM. A Hybrid Plant with Biomass. Third Int Symp Energy from Biomass Iste 2010.

[16] Moreno Merino L, Imbern Fernández N, Durán Valsero JJ, Aguilera H. Concentrating solar power plants versus groundwater resources in Mediterranean areas of Spain: The environmental dilemma. J Environ Manage 2018;206:409-17.

[17] Norton B. Harnessing Solar Heat. Netherlands: Springer; 2014.

[18] Morrone P, Algieri A, Castiglione T. Hybridisation of biomass and concentrated solar power systems in transcritical organic Rankine cycles: A micro combined heat and power application. Energy Convers Manage 2019;180:757-68.

[19] Bachelier C, Jäger W. Thermal and hydraulic evaluation of a linear Fresnel solar collector loop operated with molten salt and liquid metal. Appl Energy 2019;248:207-16.

[20] Agrela F, Cabrera M, Morales MM, Zamorano M, Alshaaer M. Biomass fly ash and biomass bottom ash. New Trends in Eco-efficient and Recycled Concrete. 2018;3:23-58.

[21] Doherty W, Reynolds A, Kennedy D. (2015) Process Simulation of Biomass Gasification Integrated with a Solid Oxide Fuel Cell Stack. J Power Sources 2015;277:292-303.

[22] Hussain.C.M.I, Duffy A, Norton B. A Comparative Technological Review of Hybrid CSP-Biomass CHP Systems in Europe, International Conference on Sustainable Energy Environmental Protection, Paisley, UK 2015; 122-130.

[23] Nation DD, Heggs PJ, Dixon-Hardy DW. Modelling and simulation of a novel Electrical Energy Storage (EES) Receiver for Solar Parabolic Trough Collector (PTC) power plants. Appl Energy 2017;195:950-73.

[24] Mahmood M, Traverso A, Traverso AN, Massardo AF, Marsano D, Cravero C. Thermal energy storage for CSP hybrid gas turbine systems: Dynamic modelling and experimental validation. Appl Energy 2018;212:1240-51.

[25] Liu M, Tay Steven, Bell S, Belusko M, Jacob R, Will G, et al. Review on concentrating solar power plants and new developments in high temperature thermal energy storage technologies. Renew Sustain Energy Rev 2016;53:1411-32.

[26] Ding Y, Li Y, Liu C, Sun Z. Solar Electrical Energy Storage. Chapter 2; Solar Energy Storage; Elsevier Ltd.; 2015. ISBN: 978-0-12-409540-3.

[27] Bai Z, Liu O, Lei J, Wang X, Sun J, Jin H. Thermodynamic evaluation of a novel solar-biomass hybrid power generation system. Energy Convers Manage 2017;142:296-306.

[28] Oyekale J, Heberle F, Petrollese M, Brüggemann D, Cau G. Biomass retrofit for existing solar organic Rankine cycle power plants: conceptual hybridization strategy and techno-economic assessment. Energy Convers Manage 2019;196:831-45.

[29] Pantaleo AM, Camporeale SM, Sorrentino A, Miliozzi A, Shah N, Markides CN Hybrid CSP-biomass combined Brayton/organic Rankine-cycle plants integrated with thermal storage: techno-economic feasibility in selected Mediterranean areas. Renewable Energy 2018:1-19.

[30] Li Y, Jing D. Investigation of the performance of photovoltaic/thermal system by a coupled TRNSYS and CFD simulation. Sol Energy 2017;143:100-12.

[31] Biencinto M, González L, Valenzuela L. A quasi-dynamic simulation model for direct steam generation in parabolic troughs using TRNSYS. Appl Energy 2016;161:133-42.

[32] Ibáñez M, Cabeza LF, Solé C, Roca J, Nogués M. Modelization of a water tank including a PCM module. Appl Therm Eng 2006;26:1328-33.

[33] Flores B, Franilena M. Analysis of a Concentrating Solar Power Generation System With Biomass Boilers Thesis Central University of Venezuela; 2014

[34] TESS. TRNSYS 17. Thermal Energy Systems Specialists, User Manual, 2012; vol. A3.

[35] Olsson O, Vinterbäck J, Porsö C. EUBIONET 3: WP3 - Wood fuel price statistics in Europe -. D 2011;3(1):1-23.

[36] Bates J. Potential Biomass Prices in Ireland, Final Report for SEAI: Version 5, 2017. Ricardo/ED10952/5.

[37] Keränen J, Alakangas E. Report on the competition and price situation of wood biomass use in forest industry and energy sector. D7.1. VTT Rep 2011;3.

[38] Bet Sarkis R, Zare V. Proposal and analysis of two novel integrated configurations for hybrid CSP-biomass power generation systems: Thermodynamic and economic evaluation. Energy Convers Manage 2018;160:411-25.

[39] Contestabile M, Elshurafa A, Farag H, Nezamuddin N, Zamrik T. Policy Brief; A Framework for Fuel and Technology Transitions in Energy : Evaluating Policy Effectiveness, 2014; KS-1404-WB02A.

[40] Perilhon C, Alkadee D, Descombes G, Lacour S. Life cycle assessment applied to electricity generation from renewable biomass. Energy Procedia 2012;18:165-76.

[41] Odavi P, Zeki V, Mili D. Life cycle cost of biomass power plant - Monte Carlo simulation of investment. Econ Agric 2017;2:587-600.

[42] Ilas Andrei, Ralon Pablo, Rodriguez Asis, Taylor Michael. Renewable Power Generation Costs in 2017, International Renewable Energy Agency. IRENA: Abu Dhabi; 2018.

[43] Concentrated solar power: renewable energy technologies: cost analysis series. IRENA Working paper; 2012: 1: 2/5

[44] Guédez R. A Techno-Economic Framework for the Analysis of Concentrating Solar Power Plants with Storage (PhD Thesis) KTH Royal Institute of Technology; 2016.

[45] Jacob R, Saman W, Bruno F. Capital cost expenditure of high temperature latent and sensible thermal energy storage systems. AIP Conf Proc 2017; 1850..

[46] Wagner SJ, Rubin ES. Economic implications of thermal energy storage for concentrated solar thermal power. Renewable Energy 2014;61:81-95.

[47] Hauer, Andreas, Thermal Energy Storage IEA-ETSAP and IRENA, Technology Policy. Brief E17, 2013. 